\title{
A model-based assessment of the effects of projected climate change on the water resources of Jordan
}

Article

Accepted Version

Wade, A. J., Black, E. C. L., Brayshaw, D. J., El-Bastawesy, M., Holmes, P. A. C., Butterfield, D., Nuimat, S. and Jamjoum, K. (2010) A model-based assessment of the effects of projected climate change on the water resources of Jordan. Philosophical Transactions of the Royal Society. Part A, 368 (1931). pp. 5151-5172. ISSN 1364-503X doi:

https://doi.org/10.1098/rsta.2010.0207 Available at https://centaur.reading.ac.uk/8197/

It is advisable to refer to the publisher's version if you intend to cite from the work. See Guidance on citing.

To link to this article DOI: http://dx.doi.org/10.1098/rsta.2010.0207

Publisher: The Royal Society

All outputs in CentAUR are protected by Intellectual Property Rights law, including copyright law. Copyright and IPR is retained by the creators or other copyright holders. Terms and conditions for use of this material are defined in the End User Agreement. 


\section{CentAUR}

Central Archive at the University of Reading

Reading's research outputs online 
Journal:

PHILOSOPHICAL TRANSACTIONS OF THE ROYAL SOCIETY A

Article id: $\quad$ RSTA20100207

Article Title: A model-based assessment of the effects of projected climate change on the water resources of Jordan

First Author: A. J. WADE

Corr. Author: A. J. WADE

\section{AUTHOR QUERIES - TO BE ANSWERED BY THE CORRESPONDING AUTHOR}

The following queries have arisen during the typesetting of your manuscript. Please answer these queries by marking the required corrections at the appropriate point in the text.

\begin{tabular}{|c|c|}
\hline AQ1 & $\begin{array}{l}\text { Reference US Geological Survey (1998) has been cited in text } \\
\text { not provided in the list. Please supply reference details or delete } \\
\text { the reference citation from the text. }\end{array}$ \\
\hline AQ2 & $\begin{array}{l}\text { Can 'north-northeast of Dana' be changed to 'northeast of } \\
\text { Dana'? }\end{array}$ \\
\hline AQ3 & $\begin{array}{l}\text { Please update references Black et al. (in press); Menzel et al. } \\
\text { (in press); Wade (in press } a, b) \text { and Wilby et al. (in press). }\end{array}$ \\
\hline AQ4 & $\begin{array}{l}\text { Please provide location details for references IPCC (2007); } \\
\text { Oroud (2008) and Suppan et al. (2008). }\end{array}$ \\
\hline AQ5 & $\begin{array}{l}\text { Please provide page range for references Kunstmann et al. } \\
\text { (2005) and Lancaster \& Lancaster (1999). }\end{array}$ \\
\hline AQ6 & $\begin{array}{l}\text { Please mention date/month the conference took place for } \\
\text { reference Kunstmann et al. }(2005) \text {. }\end{array}$ \\
\hline AQ7 & Please list up to 10 authors for reference le Quéré et al. (2009). \\
\hline AQ8 & Please mention the initials for author Schaldach. \\
\hline AQ9 & Please mention publication details for reference Tipping (2007). \\
\hline AQ10 & $\begin{array}{l}\text { Please provide a running head of not more than } 40 \text { characters, } \\
\text { including spaces. }\end{array}$ \\
\hline AQ11 & $\begin{array}{l}\text { Please provide volume and issue details for references Hemming } \\
\text { et al. (this volume) and Jin et al. (this volume). Also supply } \\
\text { reference details in the list. }\end{array}$ \\
\hline
\end{tabular}




\title{
A model-based assessment of the effects of projected climate change on the water resources of Jordan
}

\author{
By A. J. WAde ${ }^{1, *}$, E. Black ${ }^{2}$, D. BrayshaW ${ }^{2}$, M. El-BastawesY ${ }^{3}$, \\ P. A. C. Holmes ${ }^{4}$, D. Butterfield ${ }^{1}$, S. Nuimat ${ }^{5}$ and K. Jamjoum ${ }^{5}$ \\ ${ }^{1}$ School of Human and Environmental Sciences, and ${ }^{2}$ National Centre for \\ Atmospheric Science-Climate, Department of Meteorology, University of \\ Reading, 2 Earley Gate, Whiteknights, PO Box 243, Reading RG6 6BB, UK \\ ${ }^{3}$ National Authority for Remote Sensing and Space Sciences, 23 Joseph \\ Tito Street, El-Nozha El-Gedida, Cairo 11511, Egypt \\ ${ }^{4}$ Water Resource Associates, PO Box 838, Wallingford, Oxon OX10 9XA, UK \\ ${ }^{5}$ National Centre for Agricultural Research and Technology Transfer, \\ PO Box 639, Baq'a 19381, Jordan
}

This paper is concerned with the quantification of the likely effect of anthropogenic climate change on the water resources of Jordan by the end of the twenty-first century. Specifically, a suite of hydrological models are used in conjunction with modelled outcomes from a regional climate model, HadRM3, and a weather generator to determine how future flows in the upper River Jordan and in the Wadi Faynan may change. The results indicate that groundwater will play an important role in the water security of the country as irrigation demands increase. Given future projections of reduced winter rainfall and increased near-surface air temperatures, the already low groundwater recharge will decrease further. Interestingly, the modelled discharge at the Wadi Faynan indicates that extreme flood flows will increase in magnitude, despite a decrease in the mean annual rainfall. Simulations projected no increase in flood magnitude in the upper River Jordan. Discussion focuses on the utility of the modelling framework, the problems of making quantitative forecasts and the implications of reduced water availability in Jordan.

Keywords: climate change; water resources; hydrology; groundwater; Jordan

\section{Introduction}

Water is scarce in Jordan, and the pressure on this resource will increase as the population is projected to rise from an estimated 5.10 million today to 8.55 million by 2030 owing to natural increase and immigration (United States Statistics Division 2010). Jordan is seeking economic development, thus water is required for industrial expansion and tourism (US Geological Survey 1998). Surface waters *Author for correspondence (a.j.wade@reading.ac.uk).

Our contribution of the 14 to a Discussion Meeting Issue 'Water and society: past, present and future'. 
are already fully exploited, and most of those wadis (ephemeral streams) draining Jordan and its tributaries is shared between Israel, Jordan, Lebanon, Syria and the West Bank. The main water resource is groundwater, and there are three main aquifers in Jordan, although the full extent and water capacity of these have yet to be determined (Puri 2001; Puri et al. 2001; Puri \& Aureil 2005; Struckmeier et al. 2006). The four aquifers are the Syrian Steppe, the Hauran and Jabal Al-Arab aquifer, the Disi aquifer and the Eastern Mediterranean aquifer. In all cases, recharge is low at $15 \mathrm{~mm} \mathrm{yr}^{-1}$ or less (Puri 2001). In Jordan, trends in the groundwater salinity are unclear (US Geological Survey 2006).

Food security is poor in Jordan. In the marketing year 2005-2006, Jordan imported 93 per cent of its annual wheat and 95 per cent of its annual barley requirements (United States Department of Agriculture 2006). Vegetables are the main crops grown in northwest Jordan where the annual precipitation is highest. These crops are important to the national economy and as a food resource.

Water and food security are under further threat from the continued overabstraction of the water resource likely amplified by climate change. Between now and the end of the twenty-first century, increased near-surface air temperatures and reduced precipitation are projected for the Middle East (IPCC 2007; Krichak et al. 2007); thus, it is important to quantify the likely effects of climate change on the hydrology of the Jordan Valley and environs and to interpret this in terms of the socio-economic consequences. Other studies have looked at the water resources of the Jordan Valley and the likely changes given climate projections (e.g., Kunstmann et al. 2005; Samuels et al. 2009). A simple physically based model suggested that the water yield in Jordan would reduce by up to 60 per cent if precipitation were to decrease by 10 per cent and the region were to become $2^{\circ} \mathrm{C}$ warmer (Oroud 2008). Bou-Zeid \& El-Fadel (2002) suggested zero change in the October to April precipitation over Lebanon by the 2020s with a warming in July of $2^{\circ} \mathrm{C}$, leading to increased soil moisture deficits and irrigation demands. A major initiative in the Jordan Valley is the Globaler Wandes des Wasserkreislaufs - Jordan River (GLOWA JR) project (Hoff et al. 2006). Results show that although annual streamflow is proportional to total precipitation, provided annual precipitation exceeds $400 \mathrm{~mm}$, a projected increase in the frequency of wet spells lasting longer than 3 days may result in more frequent and more intense floods in the upper Jordan (Samuels et al. 2009).

Messager et al. (2006) question the reliability of outputs from hydrological models driven with climate model data. The question of how climate change may impact on river flow is challenging because of the difficulty that climate models have with representing spatial and temporal variability in daily rainfall and the structural and parameter uncertainty in hydrological models. Wilby et al. (in press) also note that there is little consensus between climate model output in the Middle East and North Africa region. Thus, modelled forecasts of future river flows are uncertain, although multiple climate model applications that consider a range of emission scenarios can help build confidence or otherwise in projected changes. Despite this, individual model simulations are still useful as they contribute to the total number of model runs available for analysis and, as in this case, provide an example of how climate model output can be used in a modelling framework to assess changes in runoff. 
The aim of this work is to develop and test a new meteorological and hydrological model framework and to assess the output from this new model chain to assess the likely impacts of climate variability and change on water availability in Jordan. Specifically, the objectives are as follows:

\section{Study areas and data resource}

\section{(a) The upper River Jordan}

In this study, the upper Jordan $\left(1752 \mathrm{~km}^{2}\right)$ is defined as the catchment area from the headwaters to the Obstacle Bridge gauging station $\left(33.03^{\circ} \mathrm{N}, 35.62^{\circ} \mathrm{E}\right)$. This study area was chosen because of its importance in terms of water provision to Jordan, the West Bank and Israel (figure 1). The headwaters of the Jordan drain from Lebanon and from Mount Hermon in the Golan Heights, the highest point in the catchment $(2814 \mathrm{~m})$, where precipitation can fall as snow during the winter. The key tributaries of the upper Jordan are the Dan, Snir (of which the Hasbani is a tributary) and the Hermon (of which the Banias is a tributary). The geology of the upper Jordan is predominately limestone, which includes Karst development. The springs, which form the Dan river, drain from the Karst, and the groundwater sustaining the spring flow is estimated to have a retention time of 2-3 years (Rimmer \& Salingar 2006). The upper Jordan drains into the Sea of Galilee, and the outlet, which supplies the lower Jordan River, is located near Degania Bet, Israel. Downstream of the Sea of Galilee, the Yarmouk drains into the Jordan River. The King Abdullah Canal is used to provide water for irrigation in northwest Jordan, and water is diverted from the lower Yarmouk to supply the canal, thereby lowering flows in the Yarmouk and the Jordan River. Water is abstracted for irrigation in Israel using the National Water 
A. J. Wade et al.

148

149

150

151

152

153

154

155

156

157

158

159

160

161

162

163

164

165

166

167

168

169

170

171

172

173

174

175

176

177

178

179

180

181

182

183

184

185

186

187

188

189

190

191

192

193

194

195

196

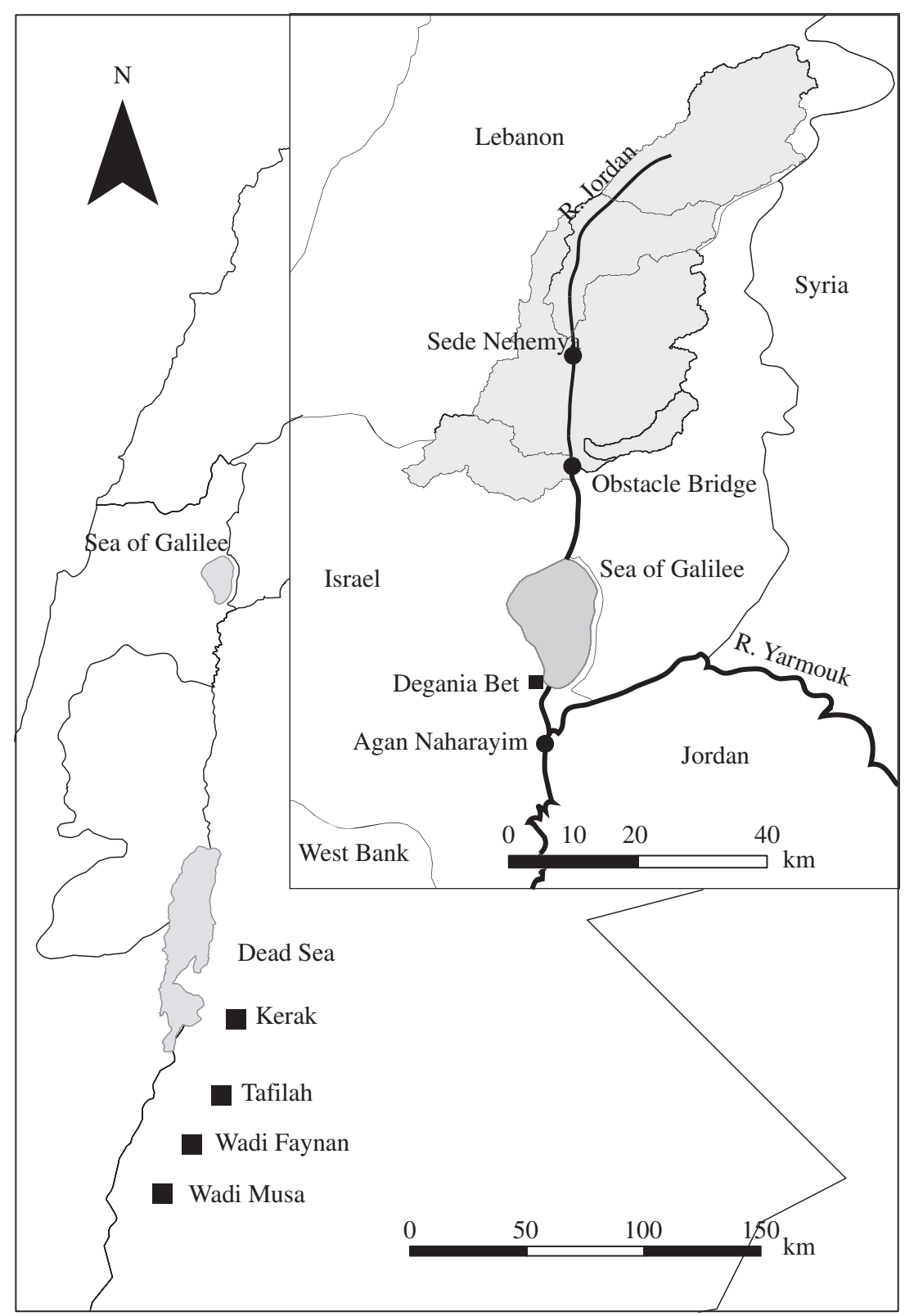

Figure 1. The location of the study sites with an inset schematic map of the upper River Jordan. Square, daily rainfall; circle, daily discharge.

Carrier, which draws water upstream of the inlet to the Sea of Galilee, and this also lowers flow in the Jordan River. Downstream of the confluence with the Yarmouk, the Jordan River flows southward to the Dead Sea where over the past 30 years, water levels have dropped at the rate of $0.5 \mathrm{~m} \mathrm{yr}^{-1}$ as a result of over-abstraction. 
Precipitation patterns in Jordan show a strong gradient from west to east. The main storm track affecting northern Jordan is from west to east along the Mediterranean Sea. Precipitation in the south of Jordan can be affected by low pressure systems over the Red Sea, known as Red Sea lows, particularly in the boreal autumn and spring (Alpert et al. 2004). The mean annual precipitation over Israel is $500-900$ and $200-700 \mathrm{~mm}$ in the northwest of Jordan, where the majority of the crops are cultivated. Wadi Araba, the valley along the IsraelJordan border, is an extension of the Great Rift of Africa. This valley affects the precipitation distribution. To the east of the valley axis is a scarp slope. Along the ridge of the scarp slope and into northwest Jordan, which is at an elevation of between $400 \mathrm{~m}$ above sea level at Umm Qais in the north and $1727 \mathrm{~m}$ above sea level at Jebel Mubrak in the south, the mean annual rainfall tends to be higher $\left(200-700 \mathrm{~mm} \mathrm{yr}^{-1}\right.$ ) than in the valley bottom (approx. $50 \mathrm{~mm} \mathrm{yr}^{-1}$ ), which, at the Dead Sea, is approx. $400 \mathrm{~m}$ below sea level. The scarp slope causes orographic lifting of the moist air masses moving east over Israel and the valley, and this leads to greater precipitation over the ridge of the scarp. Further east, towards the desert centre, the rainfall is much lower at approximately $60 \mathrm{~mm} \mathrm{yr}^{-1}$ at Ma'an and along the 'pan-handle' of Jordan towards the border with Iraq.

The spatial coverage of readily available meteorological and hydrological data is sparse. For the purpose of this study, data were collated from 60 rainfall stations and 7 discharge gauging stations across Israel, Syria, Lebanon, the West Bank and Jordan. Daily rainfall data were purchased from the Israeli Meteorological Service for the period 1984-2005 for nine sites, and further daily rainfall data were available for seven stations in Jordan from 1937 to 1974 from the yearbooks of the Water Resources Division of the National Resources Authority. Monthly rainfall data were available from the United States National Climate Data Centre for 11 sites in Israel (1846-1995), 11 sites in Jordan (1960-2000), 15 sites in Lebanon (1888-2000) and 7 sites in Syria (1951-2000).

Daily flow data were, in general, difficult to find, but these are needed to assess the flood extremes. Ideally, $15 \mathrm{~min}$ data should be used, but no such data were available for this study. Daily data from the United States National Climate Data Centre were available for flow gauges on the Jordan at Sede Nehemya (1984-1992), Obstacle Bridge (1973-1993) and Naharayim (1988-1993). The Naharayim gauging station is located downstream of the confluence of the Jordan and Yarmouk rivers, and although daily measurements are available for the period 1988-1993, the flows at this point are heavily modified by upstream abstractions to supply the National Water Carrier and the King Abdullah Canal. Monthly flow data were available at six stations, and daily and monthly flows were reported for gauges in the 1963 Jordan Hydrological year book (Central Water Authority 1963). This yearbook includes flows for the main channel of the Jordan and contributing side wadis. It should be noted, however, that in many cases, the flows for the side wadis were estimated using engineering calculations (flood hydrographs) rather than measurements. The flow in dryland systems is notoriously difficult to measure as rainfall is infrequent and large floods can damage measuring structures.

The rainfall and runoff data were supplemented with data describing the local climate at 12 sites across Jordan. These data included monthly averages for the period 1983-2002 for precipitation, near-surface air temperature, solar radiation, wind speed and sunshine hours. 


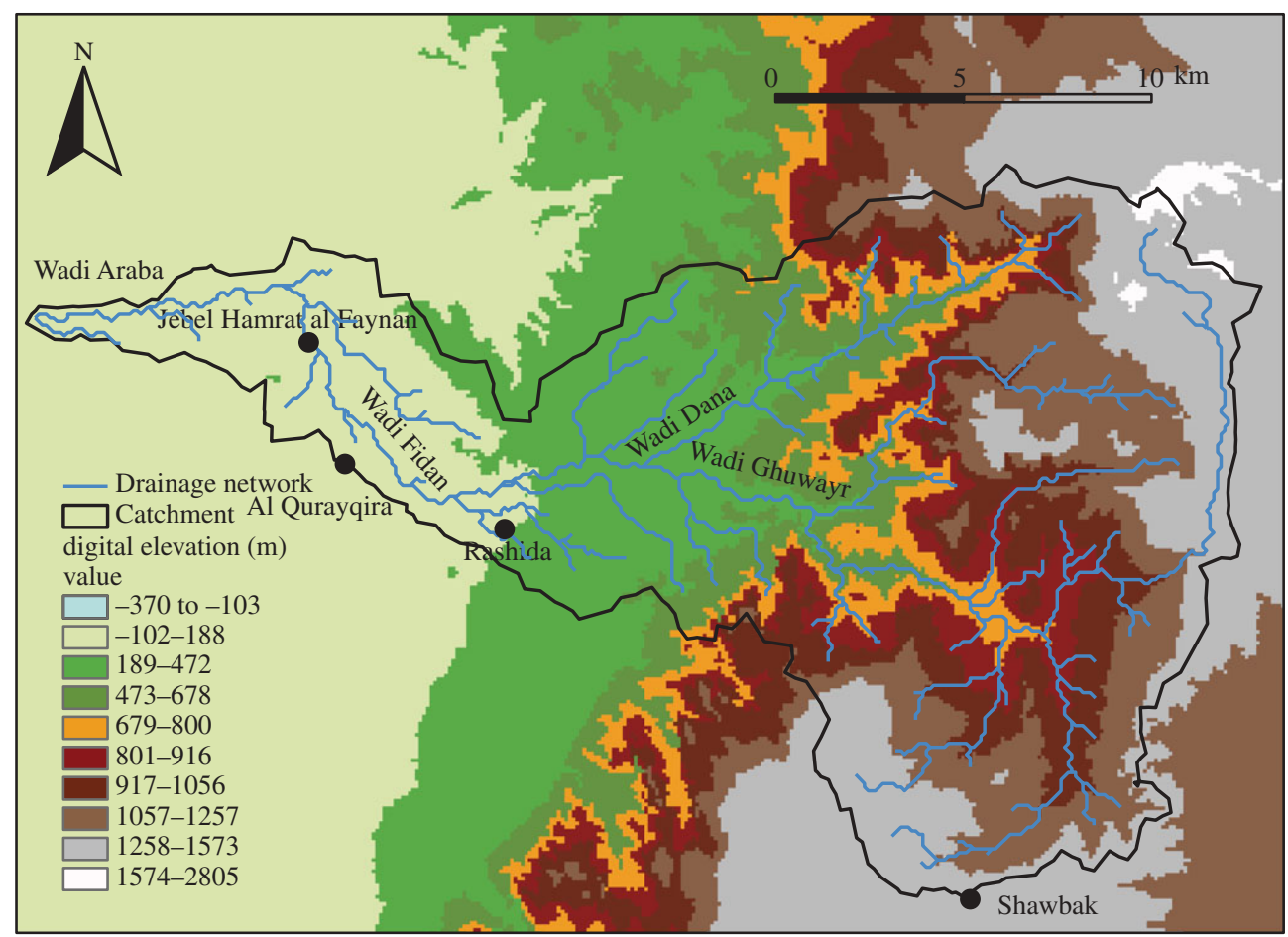

Figure 2. A topographic map of the Wadi Faynan.

Land surface elevation data for the Middle East region were obtained from the Shuttle Radar Topography Mission (SRTM) Digital Elevation Model (DEM). This dataset has a resolution of $90 \mathrm{~m}$ and a vertical accuracy of $15 \mathrm{~m}$. Land cover was taken from the Global Land Cover Map 2000 (v. 1.1) downloaded from the HYDE land cover database (Klein Goldewijk 2001).

\section{(b) The Wadi Faynan}

The Wadi Faynan drains the eastern scarp slope of Wadi Araba, south of the Dead Sea (figures 1 and 2), and is approximately $25 \mathrm{~km}$ long flowing east to west. The Wadi Faynan $\left(241 \mathrm{~km}^{2}\right)$ disgorges to Wadi Araba after passage through the Jebel Hamrat al Fidan, an Aplite-granite mass located at the mouth of the Wadi Fidan; the Wadi Fidan is the name given to the extension of Wadi Faynan between Al Qurayqira and Jebel Hamrat al Fidan. The climate of Wadi Faynan is currently classified as semi-arid as annual potential evaporation exceeds precipitation (Al-Qawabah et al. 2003). The Wadi Faynan has two major tributaries, the Wadi Ghuwayr and the Wadi Dana, developed along two NE-SW trending geological faults (Tipping 2007; figure 2).

The Wadi Faynan region has a rich archaeological heritage comprehensively described in several recent volumes (Barker et al. 2007; Finlayson \& Mithen 2007; Hauptmann 2007). Given that the focus of this paper is the hydrology, the archaeology is not considered further. Today, the Bedouin located in the Wadi Faynan use the perennial water flowing from springs in the Wadi Ghuwayr to 
irrigate their fields near the villages of Al Qurayqira and Rashida by conveying the water in plastic pipes under gravity from the mid-reaches of the wadi. There are no major urban centres in the catchment, with the population being sparse in comparison to that of northwest Jordan where the rainfall and topography are more favourable for irrigation
(Al-Qawabah et al. 2003).

Geological and hydrological information was derived from digital and paper maps and field-based measurements. The geology of the Wadi Faynan comprised fluvial deposits and eolian sands from the Quaternary period; limestones from the Eocene/Paleocene and Cretaceous periods; sandstones from the Cambrian period, and Porphyrite and Aplite-granite from the Precambrian eon. There is also an outcrop of basalt from the Quaternary on the northeast rim of the catchment, which forms the Jebel al Afa'ita. The Wadi Ghuwayr and the Wadi Dana have contrasting geology, and springs are also found in the Wadi Dana and are used to irrigate gardens and to supply a hotel, though the water from these does not typically reach the Wadi Faynan. The highest point in the Wadi Faynan catchment is Jebel Al Afa'ita at $1641 \mathrm{~m}$ above sea level. The elevation of the confluence with the Wadi Araba in the Rift Valley is $300 \mathrm{~m}$ below sea level. The range in altitude on the scarp slope varies from approximately $300 \mathrm{~m}$ above sea level at the Ghuwayr-Dana confluence on the alluvial plain to $1300 \mathrm{~m}$ above sea level on the plateau.

Hydrological measurements were collated from previous academic, government agency and engineering studies. These data were integrated with new field measurements of baseflow, open-channel hydraulics (to estimate flood peaks) and water chemistry during field visits in 2006, 2007 and 2008. There was recourse to satellite imagery to confirm the presence of specific geological structures and to verify the catchment boundaries of the study area derived from the SRTM DEM. The full details of these data and the sampling and analysis methods are given in Wade et al. (in press a).

Rainfall patterns in the region of Faynan are dominated by the orographic effect of the rift escarpment, and the area of highest annual rainfall follows a north-south line between Kerak, Tafilah and the Wadi Musa (figure 1). Mean annual rainfall across the Wadi Faynan catchment decreases from $400 \mathrm{~mm} \mathrm{yr}^{-1}$ at El Atate on the plateau to $50 \mathrm{~mm}$ in the Rift Valley floor; the latter is in a rain shadow being surrounded by highlands. The mean annual rainfall at Shawbak, which is located on the plateau on the southern boundary of the Faynan catchment, is $312 \mathrm{~mm} \mathrm{yr}^{-1}$, with a standard deviation of $136 \mathrm{~mm} \mathrm{yr}^{-1}$ (Tarawneh \& Kadioğlu 2003). Rainfall generally occurs between October and May, as elsewhere in Jordan. During winter, the precipitation can fall as snow on the plateau (Al-Qawabah et al. 2003).

The air temperatures in the Dana Reserve, which are assumed to be representative of those in the Wadi Faynan, are typically a mean of $9^{\circ} \mathrm{C}$ and $27^{\circ} \mathrm{C}$ during January and August, respectively (Al-Qawabah et al. 2003). The mean annual potential evaporation measured at Tafilah during the period 1999-2003 was $1978 \mathrm{~mm} \mathrm{yr}^{-1}$ (EMWATER 2005; Hashemite Kingdom of Jordan-Meteorological Department 2006). Given the higher rainfall in winter and the lower evaporation rates, the optimum period for cropping is winter. The land cover is characterized as desert on the floor of the Wadi Araba, changing to steppe in the mid and upper reaches of the Wadi Faynan. 


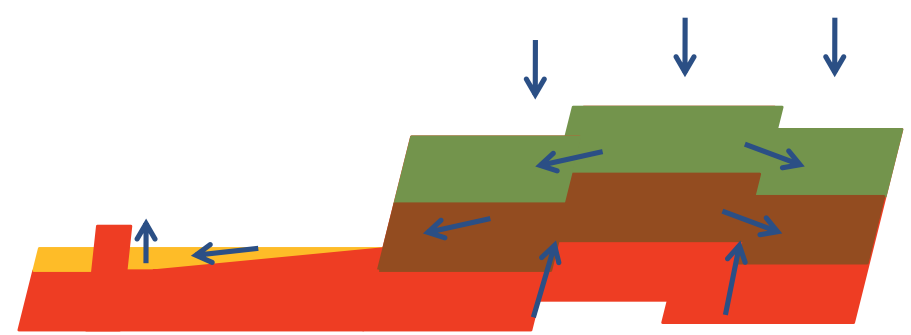

Figure 3. The conceptual model of the Wadi Faynan hydrology. This schematic is based on the geological cross-section of the Geological Map of Jordan 1:250000, prepared by F. Bender, Bundesanstait für Geowissenschaften und Rohstoffe, Hannover 1968 (Sheet: Aqaba-Ma'an and Amman). Red region, porphyrite and Aplite-granite; brown region, sandstone; green region, limestone; yellow region, alluvial sands, blue arrow, flow pathway.

A conceptual model was developed to describe the Wadi Faynan hydrology (figure 3). This model was built by integrating all the knowledge ascertained from the review of the existing and newly collected data (Wade et al. in press $b$ ). The model is as follows: the major aquifers are defined by the catchment boundary and the major aquifers are the limestone and the sandstone; groundwater recharge of the limestone and sandstone aquifers occurs through the limestone and colluvium mantle in the upper reaches of the Wadi Faynan around Dana and Shawbak; this recharge is supplemented by transmission losses from the main wadi channels to the underlying aquifers and the shallow channel alluvium; springs occur at the contact between the limestone and sandstone and between the sandstone and Precambrian volcanic rocks; the Precambrian volcanic rocks act as an impermeable layer keeping the water near the surface as it flows past from the Wadi Ghuwayr before the sand and gravels in the channel deepen in the Wadi Fidan alluvial plain and the water flows beneath the surface, possibly along the contact with the underlying Aplite-granite; the key pathways are lateral perennial flows through the limestone and sandstone with surface overland flow generated during rainfall events and snow does fall during winter in the headwaters of the catchment, but it is assumed that this will infiltrate into the well-drained soils upon melting. A full justification for these assumptions is provided in Wade et al. (in press $b$ ).

\section{Methodology}

An overview of the modelling framework is shown in figure 4. It can be seen that the framework consists of hydrological models driven by daily precipitation time series derived using a statistical rainfall model (weather generator) and climatological potential evaporation (Black et al. in press). Observed daily precipitation data were used to parametrize the weather generator, and HadRM3modelled daily precipitation data were used when making projections of flow changes. 
(a)

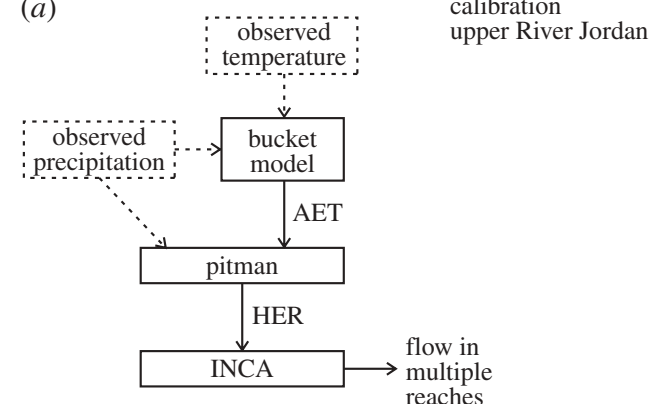

(b)

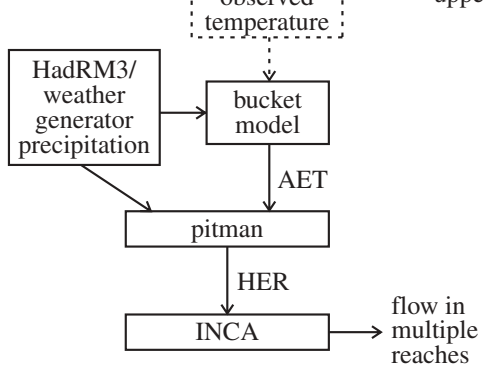

$$
\text { (c) }
$$

control (1961-1990) upper River Jordan

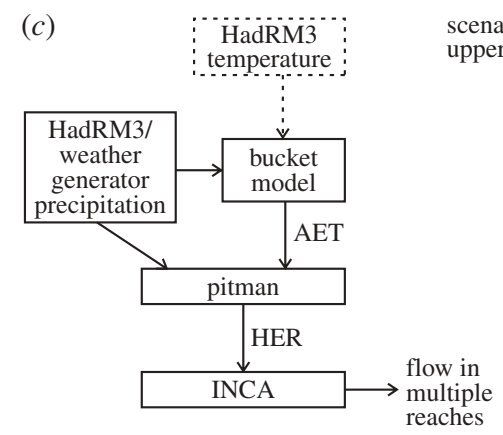

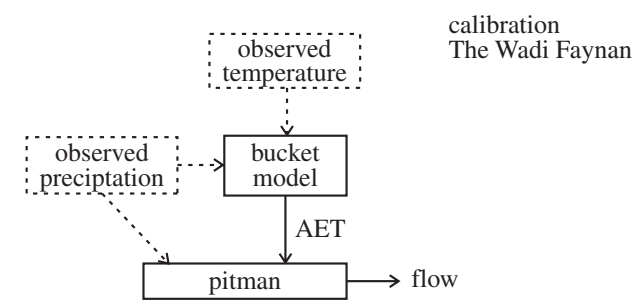

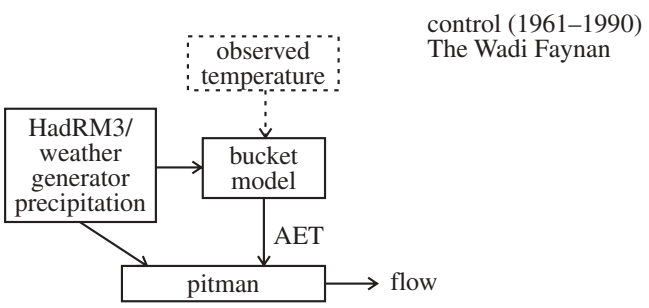

Figure 4. Overview of the modelling framework showing the data and model linkages for the upper Jordan and the Wadi Faynan applications for (a) calibration, (b) the control period (1961-1990), and $(c)$ the scenario period (2071-2100; A2).

\section{(a) Climate component of the modelling framework}

The RCM used in this study was a variant of HadRM3. HadRM3 is a regional scale climate model with a spatial resolution of $0.44^{\circ}$ (approx. $50 \mathrm{~km}$ ) for both latitude and longitude developed by the UK Hadley Centre. As such, the model has a finer spatial scale than global circulation models (GCMs) such as HadCM3, which has a spatial resolution of 3.75 by $2.5^{\circ}$ for longitude and latitude, respectively. Climate projections were extracted from HadRM3 RCM simulations of the 1961-1990 control and the 2071-2100 future periods. The output from HadRM3 was formally compared with observations in Black (2009). For the control period (1961-1990), the modelled near-surface air 
temperatures in the eastern Mediterranean were reasonably well represented. The modelled control-period precipitation data show that, while the spatial pattern of precipitation over the 30-year control period was generally modelled well, the resolution of the HadRM3 model was too coarse to capture the subtle variations in rainfall across the extension of the Rift Valley and northern Jordan. Moreover, totals. Thus, these results highlight the need for statistical downscaling, both to interpolate the RCM simulations to a point and to correct the climate model bias.

The A2 emission scenario was used for all the 2071-2100 projections. This scenario represents a world with a slow technological response to mitigate climate change and where the economic differences between the industrial and developing worlds do not narrow (IPCC 2001). The greatest changes are expected in nearsurface air temperature and precipitation by the end of the century; therefore, the scenario and the period considered represent a 'bad' case scenario. Current data suggest that global $\mathrm{CO}_{2}$ emissions are following the 'worst' case A1F1 scenario (le Quéré et al. 2009). The consideration of a single emission scenario only and the output from one RCM are limitations of the study. Despite this, the work is still useful as it explores a new modelling framework, and the results are interpreted in terms of those generated from other contemporary model-based assessments.

A weather generator was used for the control period and future scenario model runs. The weather generator is described fully and evaluated in Black et al. (in press), where it was shown that, while the weather generator was capable of reproducing the main features of the observed rainfall seasonal cycle, there were some biases - with more rain at the margins of the rainy seasons than observed. The weather generator derives rainfall stochastically, according to the underlying patterns of daily rainfall. In the weather generator used, the patterns of daily rainfall were described statistically through the mean rain per rainy day (rainfall intensity) and the probabilities of rain both given rain the day before (PRR) and given no rain the day before (PDR). PRR and PDR were calculated separately and varied by season. In the summer, when rainfall is low, both PDR and PRR were set to 0.01 ; in the rainy season, PDR varies from approximately 0.15 to 0.25 with lower values at the margins of the rainy seasons and PRR from approximately 0.55 to 0.65 . The distribution of rainfall intensities (rain per rainy day) was based on the observed time series, with an extra parameterization for extreme rainfall events. The distribution was adjusted to take into account changes in the rain per rainy day in the future scenarios. For the upper Jordan and the Wadi Faynan applications, rainfall observations from Degania Bet and Tafilah were used, respectively. For the future scenario integrations, the changes in rainfall occurrence probabilities (as defined above) were derived from the regional model integrations. In order to correct for model bias, these changes were then applied to the observed probabilities.

\section{(b) Hydrological components of the modelling framework}

The hydrological components of the model framework are the Pitman rainfall-runoff model and the Integrated Catchments model (INCA v. 1.11.10). The Pitman model is a conceptual, process-based model of the rainfall-runoff relationship (Pitman 1973). The Pitman model was chosen because it is a model developed in South Africa for semi-arid hydrological conditions and forms a 
trade-off between model complexity, data requirements and useful model output appropriate for the aims of this study. The Pitman model was designed to be applicable at the catchment scale and, in this study, was applied at the daily time step to investigate flood characteristics. The Pitman model does not include flow-routing for multiple reaches.

INCA is a hydrological and water quality model that incorporates a simple, flow-routing model that divides the main channel into a user-defined number of reaches (Whitehead et al. 1998; Wade et al. 2002). For this study, only the hydrological components of the INCA model were used. To apply the INCA model, it was necessary to determine the hydrologically effective rainfall (HER) to calculate the water volume contribution from the catchment each day. The HER is the rainfall that contributes to the river flow after evapotranspiration losses and replenishment of the soil moisture deficit are accounted for. In this study, HER was calculated using the Pitman rainfall-runoff model and a buckettype soil moisture deficit model to calculate the actual evaporation (figure 4). Thus, together the Pitman and INCA models allowed the calculation of the runoff response to rainfall for the upper River Jordan. INCA was not applied at the Wadi Faynan.

\section{(c) Model set-up and calibration for the upper River Jordan}

The Pitman model was configured to simulate the surface and groundwater flows and to calculate the HER at a daily time step using observed precipitation and an estimate of the actual evapotranspiration (AET) by a bucket-type soil moisture model based on the Penman equation. The mean annual HER was estimated as 45 per cent of the mean annual precipitation input and thereby in agreement with the estimate of Kunstmann et al. (2005). The estimated HER was input to the INCA model, which was then used to route water along the upper reaches of the River Jordan with a daily time resolution. The INCA water balance is computed on a $1 \times 1 \mathrm{~km}$ grid cell, and this is then multiplied by the unit area in each subcatchment to calculate the volume of water transferred from the unit to the main channel. Within each subcatchment, different landscape units are specified according to soil, land use and geological types. The INCA model has two reservoirs in each landscape unit: one represents the flow of water through the unsaturated zone, incorporating the soil, and the other represents the groundwater.

Initially, the entire Jordan River basin was subdivided into 19 reaches based on gauging stations and points just downstream of major confluences with tributaries and side wadi channels. The Dead Sea was included and, of the defined reaches, this had the largest drainage area of $49000 \mathrm{~km}^{2}$. The following land cover types, selected from the Global Land Cover Map 2000, were also initially included in the INCA application: broadleaved tree cover (open), shrub cover, cultivated, bare areas, inland water and urban. Shrub cover for the INCA application included closed or open cover, deciduous, sparse herbaceous or sparse shrub cover and regularly flooded shrub and/or herbaceous cover. In practice, it was not possible to use 19 reaches nor to differentiate between land cover types because of a lack of data to calculate the AET for each. Thus, Pitman was set-up for a compound single land cover as was the INCA model. 


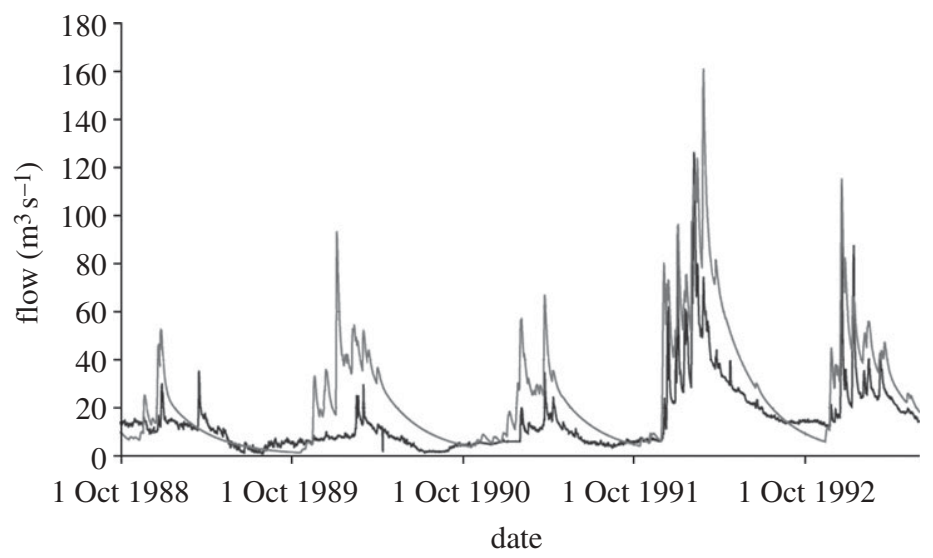

Figure 5. Modelled (grey line) and observed (black line) mean daily flows in the Jordan River at Obstacle Bridge from 1 October 1988 to 30 September 1993. Black line, observation; grey line, calibration.

During the study, it became apparent that only limited daily time-step discharge data could be obtained. Given that the purpose was to look at extremes in flow, this cannot be done with monthly flow data. Downstream of the Sea of Galilee at Naharayim, the observed flows were heavily modified by the upstream abstractions. Thus, the INCA model was applied to the upper four successive reaches (figure 1) from the headwaters to the discharge gauging station at Obstacle Bridge in Israel. The flows measured at Obstacle Bridge were not as heavily modified as at Naharayim so the hydrological response to climate could be better determined.

For the upper River Jordan, the INCA model was calibrated for the period 1 October 1988 to 30 September 1993 (figure 5). The purpose of the calibration was to set the values of the model parameters, and this period was chosen to provide the maximum overlap of available daily rainfall from Degania Bet and flow data from Obstacle Bridge. The unsaturated and the groundwater zone residence times, the instream routing parameters that control the reach residence times and the baseflow indices were adjusted until the modelled output flow matched, as closely as possible, the observed flow time series at Obstacle Bridge. There were insufficient data to perform a split-sample test and to assess the model performance for a second period.

The INCA model performance was assessed using the $R^{2}$-value and the NashSutcliffe criterion. The $R^{2}$-value for the calibration period was 0.7 , and the Nash-Sutcliffe criterion was negative. This result indicates that the pattern in the observed flows was simulated, but the actual values were not replicated. This was due to an inability to quantify the volume of abstractions in the upper Jordan owing to a lack of data. Despite this inability to quantify the abstractions, the study is still useful as it provides an indication of how water availability will change relative to the present and the control period.

Once INCA was calibrated, the control period rainfall data derived from HadRM3 and the weather generator were input to the Pitman model to provide a second estimate of the HER for the control period for comparison with the model 
calibration. These HER data were input to INCA to derive a control period flow series. This process was repeated but using the 2071-2100 scenario precipitation data derived from the HadRM3 runs and the bias correction using the weather generator to derive, through the Pitman model, the HER for the INCA 2071-2100 scenario run. Given the difference in the estimated HER between the calibration and control period run, there was a difference in the flows simulated, but this was acceptable: the control period maximum mean daily flow was $138 \mathrm{~m}^{3} \mathrm{~s}^{-1}$ compared with $161 \mathrm{~m}^{3} \mathrm{~s}^{-1}$ during calibration and the comparative Q10 (the flow exceeded $10 \%$ of the time), Q50 and Q95 mean daily flows for the control and calibration periods, respectively, were 76 and 110, 15 and 16, 3.3 and $2.6 \mathrm{~m}^{3} \mathrm{~s}^{-1}$.

600

601

\section{(d) Model set-up and calibration for the Wadi Faynan}

The Wadi Faynan conceptual model was realized as a numerical model through calibration of the Pitman model (Wade et al. in press $b$ ). The purpose of the model application was not to quantify flood flows exactly. This could not be achieved in this case because of a lack of observed time-series flow data with which to rigorously assess the model performance. Rather, the purpose was to define a hydrological model as a best estimate of the hydrological functioning and then run scenarios to explore how changes in rainfall amounts affect flood characteristics and the baseflow.

The Pitman model was applied to the Faynan catchment, defined from a point on the channel network adjacent to the ancient field system and immediately downstream of the confluence between the Wadi Ghuwayr and the Wadi Dana (figure 2). At this point, the upstream contributing area is $115 \mathrm{~km}^{2}$. This was done as the lowest point at which the measurements of both the baseflow and peak floods were made was the outflow of the Wadi Ghuwayr and the Wadi Dana, thus allowing estimates of the baseflow and peak flow to be made at the confluence for comparison with those modelled. It was extremely difficult to survey the channel downstream of the confluence, here the alluvial plain has a width of approximately $1 \mathrm{~km}$. Modelling the catchment flows to a point on the channel network adjacent to the ancient field system also removes the complication of simulating the transmission losses and water residence (or transit) times in the alluvial plain of the Wadi Fidan and eliminates the need for a definitive understanding of the source of the Fidan spring within this model-based assessment.

This application of the Pitman model to the Wadi Faynan required daily estimates of rainfall and the potential evaporation. The use of the rainfall data from Tafilah was appropriate for the model application. Tafilah is located on the plateau $18 \mathrm{~km}$ north-northeast of Dana and receives rainfall similar to the upper reaches of the Wadi Faynan. Moreover, a substantial daily record of rainfall was available from 1 October 1937 to 30 April 1974, allowing the model to be run for a relatively long period, which is important when making an assessment of flood magnitude and frequency.

An estimate of the daily potential evaporation was derived from monthly measurements of wind speed, sunshine hours, relative humidity and air temperature available for a 2-year period from Ma'an using the Penman equation. This 2-year estimated time series was repeated to form a daily time series of 36 years, the same length as the observed daily rainfall time series. This repetition of 
638

639

640

641

642

643

644

645

646

647

648

649

650

651

652

653

654

655

656

657

658

659

660

661

662

663

664

665

666

667

668

669

670

671

672

673

674

675

676

677

678 Q11

679

680

681

682

683

684

685

686

the 2-year time series, although a clear over-simplification of the changes expected during the 36-year period, was done to allow the model to be run on a daily time step to allow progression with the model application.

It is practically impossible to separate the effects of transmission loss from those of infiltration and deep percolation when estimating groundwater recharge. As such, no attempt was made to distinguish transmission loss from infiltration to the soils and the subsequent deep percolation of water to the underlying aquifer within the simulations. Rather, the combined effects of transmission loss, infiltration to the soil and subsequent deep percolation are considered together as a single groundwater-recharge mechanism. To apply the model, estimates of the groundwater volume and infiltration rate were made (Wade et al. in press $b$ ).

The simulated flows output from the PITMAN model generally falls within the baseflow and peak flow constraints identified by field observations for model calibration (not shown). The baseflow in catchment was observed to be in the range $0.02-0.09 \mathrm{~m}^{3} \mathrm{~s}^{-1}$, and the model replicated this. The simulated annual flood ranged from 2 to $98 \mathrm{~m}^{3} \mathrm{~s}^{-1}$, and for return periods of 1-2 years, the range of the simulated floods was $2-17 \mathrm{~m}^{3} \mathrm{~s}^{-1}$, which was within broad agreement with the annual floods estimated by the survey $\left(14-22 \mathrm{~m}^{3} \mathrm{~s}^{-1}\right)$. The simulated extreme floods with return periods of $12-37$ years are lower than the estimated flow range when the channel is flowing full $\left(120-180 \mathrm{~m}^{3} \mathrm{~s}^{-1}\right)$. For only 15 per cent of the calibration time-period considered did the simulated flows increase in response to precipitation events, and this hydrological behaviour is typical of semi-arid catchments (Bull \& Kirby 2002).

\section{Results}

\section{(a) Impact of anthropogenic climate change on the regional rainfall}

A reduction in the mean annual rainfall is projected under the A2 scenario for the 2071-2100 period for the Middle East (Black 2009). In the upper Jordan, the largest monthly reductions (around 30\% in the River Jordan region) are during December and January (figure 6). The rainy season is predicted to become longer, which partially offsets the marked decrease in precipitation projected at the peak of the rainy season. At the margins of the rainy season, small increases in monthly rainfall are projected by the climate model. The reasons for this are not fully understood, but may be related to changes in the occurrence of Red Sea troughs, which are the dominant observed cause of rain in these seasons (Black 2009). The reduction in winter rainfall can be related to changes in the large-scale circulation and is predicted by most climate models (for example, Kitoh et al. 2008; Evans 2009; Hemming et al. this volume; Jin et al. this volume), the same cannot be said for the spring precipitation, which leads to large uncertainties in the prediction of rain in this season (Black et al. in press). Sensitivity studies of the hydrological response to rainfall imply that the changes in spring rainfall have relatively little impact, and hence the uncertainties in our predictions of spring rainfall do not prejudice the reliability of the predictions of flow (Wade et al. in press $a$ ). At the peak of the rainy season, the number of rainy days is projected to decrease, reflecting reductions in both the PRR and the PDR, of approx. 25 per cent (PRR reduced from approx. 0.6 to $0.4-0.5$ and PDR 


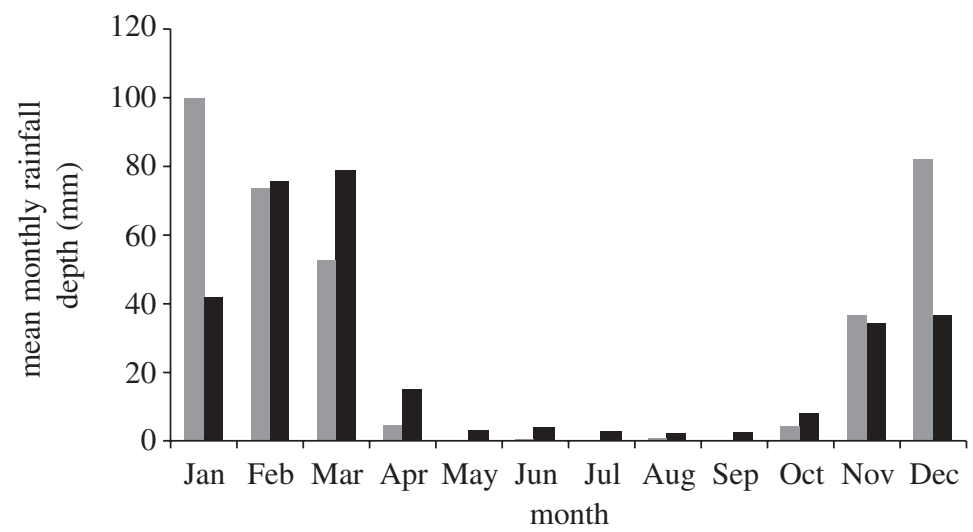

Figure 6. Projected changes in the monthly rainfall totals at Degania Bet, Israel from the HadRM3 and weather generator models for 2070-2100 under the SRES A2 scenario. Grey bars, control; black bars, 2070 A2.

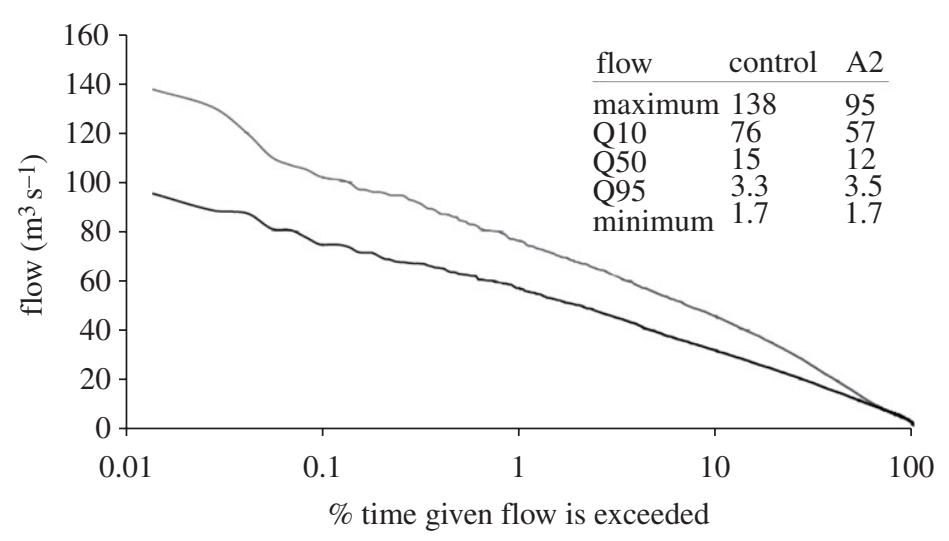

Figure 7. Modelled mean daily flows in the Jordan River at Obstacle Bridge for control (1961-1990) and scenario (2071-2100) periods. Grey solid line, control; black solid line, A2 2070s.

reduced from approximately 0.2 to 0.15 ). The overall picture is, therefore, of a longer rainy season with a less pronounced peak, with the mean annual rainfall decreasing in the headwaters of the River Jordan and the Wadi Faynan. The reduction in rainfall is accompanied by an increase in temperature by $2^{\circ} \mathrm{C}$ and hence evaporation increases.

\section{(b) Impact of anthropogenic climate change on flow in the upper River Jordan}

In comparison to the control period, the modelled outcome for the 2071-2100 A2 scenario is that the low (base) flows will remain similar to those occurring at present; there is little difference in the forecast median (Q50) flows, and the Q50 in the control and scenario periods are 15 and $12 \mathrm{~m}^{3} \mathrm{~s}^{-1}$, respectively (figure 7 ). 


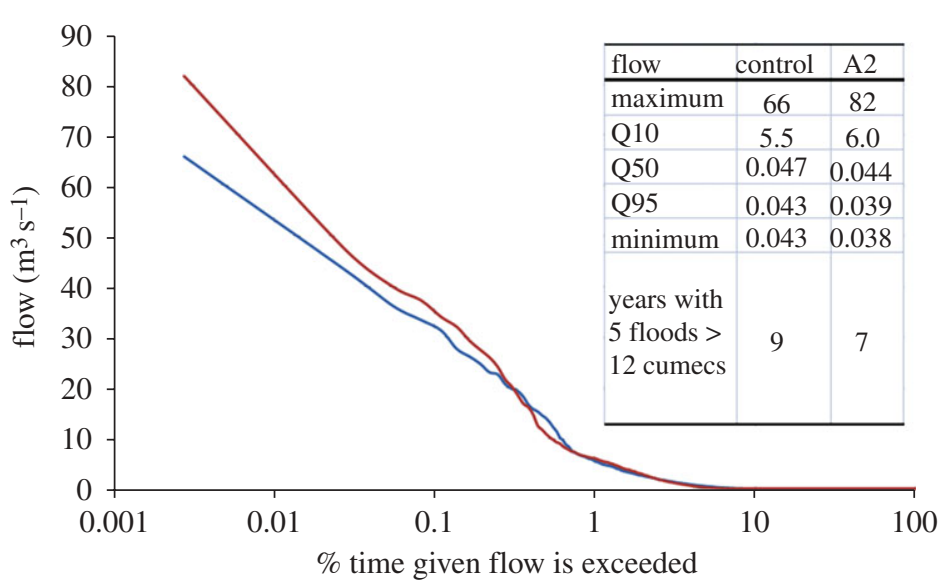

Figure 8. Modelled mean daily flows in the Jordan River in the Wadi Faynan for control (1961-1990) and scenario (2071-2100) periods. Blue solid line, control; red solid line, A2 2070s.

This lack of response is a result of the long residence time in the groundwater component of the INCA model, which suggests that groundwater acts to buffer changes in the rainfall amounts to maintain the low and intermediate flows. The flood response is different. There is a drop in the Q10 flow (exceeded 10\% of the time) from 76 to $57 \mathrm{~m}^{3} \mathrm{~s}^{-1}$ between the control and scenario periods as a result of the reduced winter rainfall, and this indicates that flood magnitudes will be reduced. Increases in the flow extremes, in terms of flood magnitude and occurrence, are not evident, which is consistent with Black (2009), who found no significant changes in rainfall intensity in these projections for this region.

\section{(c) Impact of anthropogenic climate change on flow in the Wadi Faynan}

For the Wadi Faynan, the baseflows in the period 2071-2100 under the A2 scenario are predicted to decrease by 12 per cent (figure 8 ). The number of years with five floods greater than $12 \mathrm{~m}^{3} \mathrm{~s}^{-1}$ will decrease from 9 to 7 in the 30 -year period, and the median flow will decrease by 6 per cent. The flow threshold of five floods greater than $12 \mathrm{~m}^{3} \mathrm{~s}^{-1}$ is derived from the measurement of flows in the annual flow channel and the number of flows from Bedouin anecdotal evidence of years with good harvests (Lancaster \& Lancaster 1999; Wade et al. in press b). As a result of the projected reduced rainfall and increased near-surface temperature, the baseflow decreases as recharge declines, though because recharge is already low then the impact on the baseflow is small. Interestingly, although the mean annual rainfall decreases, the flow exceeded 10 per cent of the time (Q10), which is representative of the flood extremes, increases, and the maximum flood flow also increases; peak flows will be approximately $1.25(82 / 66)$ times what they are at present. This increase in flood extremes results from subtle changes in the distribution of rainfall intensities in the A2 scenario projections and should therefore be regarded with caution, particularly bearing in mind model bias. This caveat should also be applied to the projected flows in the upper River Jordan. 


\section{Discussion}

The RCM projections suggest that in a world that does not work to find an integrated way to reduce greenhouse gas emissions, then a temperature increase of $2^{\circ} \mathrm{C}$ and a decrease in rainfall by 25 per cent are projected in the eastern Mediterranean by the end of this century. In addition to a reduction in the mean annual rainfall, the seasonality of the rainfall will change also as the start and end of wet season are projected to become wetter, but there will be less rainfall in December and January.

In the upper River Jordan, the change in the low flows will depend on the volume of water stored in the Karst system of the northern Jordan valley and the recharge rate, both of which are poorly characterized. The modelled outcomes from the conceptual Hydrological Model for the Karst Environment (HYMKE), described in Rimmer \& Salingar (2006), corroborate the results from this study that the low flows will not change. It is unclear over what simulated time period the HYMKE model was run for the modelled scenarios. The INCA model was run for 30 years with a daily time step, so this may be sufficient to examine long-term trends but the relationship between groundwater recharge through percolation and soil moisture has not been modelled in detail. Thus, it is proposed that it will be necessary to run transient scenarios from present day to 2100 to see how the groundwater will change over the long term using both the HYMKE and INCA models and that further consideration be given to the likely groundwaterrecharge mechanisms to determine whether the current groundwater components of both models are a good representation of water storage and flow in the Karst.

In a study of the upper Jordan catchment that used a distributed hydrological model informed by RCM input, Suppan et al. (2008) predicted that under a scenario in which the present rates of greenhouse gas emission increase slowly, the total runoff will decrease by 23 per cent by the end of the twenty-first centurya conclusion consistent with the linear relationship between annual precipitation and streamflow proposed in Samuels et al. (2009). However, in contrast to Samuels et al. (2009), which suggested little change in the baseflow, Suppan et al. (2008) suggested that groundwater recharge would decrease, resulting in a reduction in the baseflow. Samuels et al. (2009) showed that increasing the frequency of rainy spells lasting 3 days or more, without changing the annual total precipitation, increased the impact of high intensity rainfall events on the River Jordan, resulting in more frequent and intense floods. The results for the hydrological projections for the Wadi Faynan corroborate this result, but the projected flows in the upper Jordan suggest that flood magnitude will not increase. This reflects the fact that, in the simulations, rainfall intensity seen in the River Jordan region in the future is very similar to that observed today, whereas in the Wadi Faynan, there is a small increase in the extreme rainy events. However, these results should be regarded with caution because the climate model represents rainfall intensity poorly. Moreover, further work is required to confirm the results of this and other studies and to verify the representation of the rainfall extremes used in the weather generator.

The reduction in the mean annual rainfall and the increase in near-surface air temperatures suggest that irrigation requirements will increase, worsening the water shortage in the region. This suggestion is supported by preliminary applications of the CROPWAT model in the Water, Life and Civilisation study 
and by applications of a soil-vegetation-atmosphere transfer (SVAT) model TRAIN, which indicate increases in evapotranspiration and water demand (Menzel et al. in press). The preliminary predictions of the CROPWAT model suggest that at Ramtha in northwest Jordan, the irrigation demand will increase from 62 to $132 \mathrm{~mm}$ of water when growing vegetables under the A2 scenario for 2071-2100 using HadRM3 and an assumed irrigation efficiency of 70 per cent. The TRAIN model provides an overview of the Jordan Valley region, and the modelled outcomes suggest a 6 per cent increase in the water demand for agriculture over the entire region and up to a 50 per cent decrease in water availability in northwest Jordan, Israel and the West Bank (HadCM3, A1B scenario, 2021-2050 compared with 1961-1990 control period). Menzel et al. (in press) note that this region includes the Negev, where water scarcity is a factor that will in effect lessen the future projection of water demand. These preliminary results highlight the local and regional differences that might be expected in irrigation demand and do not account for the possibility the crop stomata may close in response to increased near-surface air temperatures, resulting in little difference in crop evapotranspiration, but lower yields owing to the increased crop stress of an increased canopy temperature (Kimball \& Bernacchi 2006). Higher atmospheric $\mathrm{CO}_{2}$ may also reduce stomata activity. An overall increase in local and regional irrigation demand has serious implications for Jordan since further stress, including increased salinity, will be put on the groundwater resource. Israel has already invested heavily in the desalination of groundwater. Jordan may have to do likewise.

The modelling framework proposed has the same uncertainties as outlined by Wilby \& Harris (2006). These uncertainties in model application are the choice of the SRES scenario; the subsequent regional climate projections; the probabilities and rainfall intensity distribution chosen for the weather generator; the structure and calibration of the hydrological models and the sampling errors of the observed data used to define the structure and parameters of the model ensemble. In particular, there are limited daily flow data with which to calibrate and test the hydrological models, not only in the upper Jordan but also in the side wadis and other tributaries that comprise the Jordan drainage network. As such, this and other model chains cannot provide absolute changes in the rainfall-runoff response, but rather give an indication of the possible changes in the distribution of flows. Further complications in the case of the Jordan River include an inability to quantify exactly the volume of water abstracted from different reaches owing to the numerous and diffuse nature of the abstractions; further regulation or quantification of these abstractions may help manage the resource. Until such quantification is done, it will be difficult to separate the effect of abstractions from that of climate. Further investigation is also required to determine whether the use of a weather generator approach introduces bias itself, as suggested here where more rain was predicted at the margins of the rainy season than observed. In addition, further work is needed to determine how important this bias is in terms of other uncertainties such as structure of the climate model and the choice of emission scenario. A potentially fruitful method for progress in the development of coupled climate-hydrological assessments would be the determination of what aspects of the climate or weather are most critical to the hydrological assessment. The climate and weather projections from a GCM, $\mathrm{RCM}$, weather generator or a combination of these could then be tested, in terms 
of these aspects, against observation to assess reliability. In addition, further work is required to assess the capability of climate models to simulate the frequency and duration of rainfall events, as well as the magnitude. This capability assessment is required to determine how well antecedent moisture conditions and groundwater recharge can be estimated and whether the increases in the simulated rainfall extremes are valid.

Although coupling uncertainties together means that the quantification of the runoff response is likely to be inaccurate, the modelling framework can be used to explore the hydrological system and to assess the impact of different scenarios and management decisions. At present, this study is limited in that only rainfall and runoff are considered. Further work is required to understand the implications of the projected temperature and precipitation changes on other aspects of the water resource, such as groundwater recharge and soil moisture availability. This task has been started by Menzel et al. (in press), using another methodology, but further work is required to substantiate initial projections of change.

It is recommended that an ensemble approach to climate and hydrological modelling be taken to account for structural uncertainty. In particular, it is useful that a number of studies do the same thing so that results can be compared (e.g. Samuels et al. 2009). In addition, it is recommended that a study of the effects of parameter uncertainty in the INCA and Pitman models on the modelled flows be done using an ensemble of generated weather time series. Further applications of the framework proposed here and other coupled climate-hydrological approaches will allow a more extensive review of potential outcomes to population and climate change to be achieved. With such an ensemble approach, care must be taken to use the same SRES emission scenarios, time periods and spatial scale of comparison. This will require discussion and cooperation between hydrological modellers of the nature already achieved in the ENSEMBLES climate-modelling project (http://www.ensembles7eu.org). Although such an ensemble approach will be useful to quantify uncertainties, this approach should be balanced with a diversity of climate and hydrological modelling approaches that cover a range of emission scenarios and spatial scales. A diversity of approaches will help understand a range of possible futures and may explain discrepancies in the projected flows between the upper River Jordan and the Wadi Faynan.

\section{Conclusions}

This study is one of the first to combine an RCM, a weather generator and hydrological models to project the likely rainfall-runoff response of the upper River Jordan and side Wadis in Jordan, framing the results within other contemporary research. A substantial dataset has been collated to develop and test the modelling framework, and in a data-poor region, this represents a substantial undertaking. The modelled results provide a contribution to the debate about how the runoff response will change in the upper Jordan River and the side wadis of western Jordan.

Owing to the uncertainties associated with the chosen greenhouse gas emissions scenario, the RCM, the weather generator and the hydrological models, the results can only be assumed to be indicative at this stage. Nevertheless, the modelled outcomes suggest that although the mean annual flow of the River Jordan will 
reduce, the baseflow of the upper Jordan will not change significantly in response to climate change, although flood extremes may increase - a result corroborated by other comparable studies.

The results of this study suggest that the impact of precipitation decreases on the combined effects of expected population increase and the changes in the projected climate are yet to be modelled. Although the groundwater levels appear to be maintained in response to climate change alone, it is likely that they will decrease if the population increases. Water security in Jordan, and Israel and the West Bank, will probably depend on how exploitable the groundwater reserves prove to be.

This work was funded as part of the Water, Life and Civilisation Project by The Leverhulme Trust (grant no. F/00239/R). In part this grant supported Mohammed El-Bastawesy as a Visiting Researcher at the University of Reading. The authors are grateful to Frank Farquharson and Helen Houghton-Carr of the Centre for Ecology and Hydrology for access to the Overseas Archive; Sam Smith and Clare Rambeau for their assistance in the field; Nicola Flynn for her help in data collation and initial model set-up of the INCA model and Andrew Bradley for Geographical Information System derivation of the subcatchment boundaries and land cover.

\section{References}

Alpert, P., Osetinsky, I., Ziv, B. \& Shafir, H. 2004 Semi-objective classification for daily synoptic systems: application to the eastern Mediterranean climate change. Int. J. Climatol. 24, 10011011. (doi:10.1002/joc.1036)

Al-Qawabah, M. S., Johnson, C., Ramez, H. \& Al-Fattah, M. Y. A. 2003 Assessment and evaluation methodologies report: Dana Biosphere Reserve, Jordan. Sustainable Management of Marginal Drylands (Sumamad). In Proc. Second Int. Workshop Shiraz, Islamic Republic of Iran, 29 November-2 December 2003, UNESCO-MAB Drylands Series No. 3.

Barker, G., Gilbertson, D. \& Mattingly, D. (eds) 2007 Archaeology and desertification: the Wadi Faynan landscape survey, Southern Jordan. Wadi Faynan Series, vol. 2, Levant Supplementary Series 6, 510pp. Oxford,UK: Council for British Research in the Levant in Association with Oxbow Books (ISBN 1-84217-286-7).

Black, E. 2009 The impact of climate change on daily precipitation statistics for Jordan and Israel. Atmos. Sci. Lett. 10, 192-200. (doi:10.1002/asl.233)

Q3 Black, E., Hoskins, B., Slingo, J. \& Brayshaw, D. In press. Future climate of the Middle East. In Water, life and civilisation: climate, environment and society in the Jordan Valley (eds S. Mithen \& E. Black). Cambridge, UK: Cambridge University Press.

Bou-Zeid, E. \& El-Fadel, M. 2002 Climate change and water resources in Lebanon and the Middle East. J. Water Resour. Plan. Manage. 128, 343-355. (doi:10.1061/(ASCE)07339496(2002)128:5(343))

Bull, L. J. \& Kirby, M. J. 2002 Dryland river characteristics and concepts. In Dryland rivershydrology and geomorphology of semi-arid channels (eds L. J. Bull \& M. J. Kirby), pp. 3-15. Chichester, UK: Wiley.

Central Water Authority. 1963 Review of stream flow data prior to October 1963. Technical Paper No. 33, The Hashemite Kingdom of Jordan, Central Water Authority, Hydrology Division, Amman, Jordan.

EMWATER. 2005 Prospects of efficient wastewater management and water reuse in Jordan, country study. Prepared within the Framework of the EMWATER-Project, 'Efficient management of wastewater, its treatment and reuse in the Mediterranean countries', Al al-Bayt University, Mafraq, Jordan, InWEnt, Amman Office, Jordan, February 2005, p. 79.

Evans, J. P. 2009 21st century climate change in the Middle East. Clim. Change 92, 417-432. (doi:10.1007/s10584-008-9438-5) 
981

982

983

984

985

986

987

988

989

990

991

992

993

994

995

996

997

998

999

1000

1001

1002

1003

1004

1005

1006

1007

1008

1009

1010

1011

1012

1013

1014

1015

1016

1017

1018

1019

1020

1021

1022

1023

1024

1025

1026

1027

1028

1029
Finlayson, B. \& Mithen, S. J. 2007 The early prehistory of Wadi Faynan, Southern Jordan: archaeological survey of Wadis Faynan, Ghuwayr and Al Bustan and evaluation of the PrePottery Neolithic A site of WF16, Wadi Faynan Series 1, Levant Supplementary Series 4, ISBN $1-84217-212-3$.

Hashemite Kingdom of Jordan-Meteorological Department. 2006 See http://met.jometeo.gov.jo/ portal/page?_pageid=113,1,113_56210:113_56242\&_dad=portal\&_schema=PORTAL (accessed 9 August 2006).

Hauptmann, A. 2007 The archaeolmetallurgy of copper: evidence from Faynan. New York, NY: Springer.

Hoff, H., Küchmeister, H. \& Tielbörger, K. 2006 The GLOWA Jordan River project-integrated research for sustainable water management. Int. Water Assoc. Water Environ. Manage. Ser. 10, $73-80$.

IPCC 2001 Special Report on Emissions Scenarios (SRES). See http://www.grida.no/ publications/other/ipcc_sr/.

IPCC 2007 Climate Changē 200\%: the physical science basis. Contribution of Working Group I to Q4 the Fourth Assessment Report of the Intergovernmental Panel on Climate Change. Cambridge University Press.

Kimball, B. A. \& Bernacchi, C. J. 2006 Evapotranspiration, canopy temperature and plant water relations. Ecol. Stud. 187, 311-324. (doi:10.1007/3-540-31237-4_17)

Kitoh, A., Yatagai, A. \& Alpert, P. 2008 First super-high resolution model projection that the ancient 'Fertile Crescent' will disappear in this century. Hydrol. Res. Lett. 2, 1-4. (doi:10.3178/hrl.2.1)

Klein Goldewijk, K. K. 2001 Estimating global land use change over the past 300 years: the HYDE database. Global Biogeochem. Cycles 15, 417-434.

Krichak, S., Alpert, P., Bassat, K. \& Kunin, P. 2007 The surface climatology of the eastern Mediterranean region obtained in a three-member ensemble climate change simulation experiment. Adv. Geosci. 12, 67-80. (doi:10.5194/adgeo-12-67-2007)

Kunstmann, H., Suppan, P., Heckl, A. \& Rimmer, A. 2005 Combined high resolution climate and distributed hydrological simulations for the eastern Mediterranean/Near East and the Upper Jordan Catchment. In Conf. Int. Agricultural Research for Development, Tropentag StuttgartHohenheim.

Lancaster, W. \& Lancaster, F. 1999 People, land and water in the Arab Middle East: environments and landscapes in the Bilad ash-Sham. Stud. Environ. Anthropol. 2.

le Quéré, C., Raupach, M. R., Canadell, J. G., Marland, G. et al. 2009 Trends in the sources and sinks of carbon dioxide. Nat. Geosci. 2, 831-836. (doi:10.1038/ngeo689)

Menzel, L., Kock, J., Onigkeit, J. \& Schaldach. In press. Modelling the effects of land use and land cover change on water availability in the Jordan River region. Adv. Geosci.

Messager, C. et al. 2006 Influence of observed and RCM-simulated precipitation on the water discharge over the Sirba basin, Burkina Faso/Niger. Clim. Dyn. 27, 199-214. (doi:10.1007/ s00382-006-0131-y)

Oroud, I. M. 2008 The impacts of climate change on water resources in Jordan. In Climatic changes Q4 and water resources in the Middle East and North Africa (eds F. Zereini \& H. Hotzl), pp. 109123. Springer.

Pitman, W. V. 1973 A mathematical model for generating river flows from meteorological data in South Africa. Report Hydrological Research Unit, University of the Witwatersrand, Johannesburg, South Africa.

Puri, S. 2001 Internationally shared (transboundary) aquifer resource management-their significance and sustainable management. UNESCO IHP-VI Series in Groundwater, Paris.

Puri, S. \& Aureli, A. 2005 Transboundary aquifers: a global program to assess, evaluate, and develop policy. Ground Water 43, 661-668. (doi:10.1111/j.1745-6584.2005.00100.x)

Puri, S., Appelgren, B., Arnold, G., Aureli, A., Burchi, S., Burke, J., Margat, J., Pallas, P. \& von Igel, W. 2001 Internationally shared (transboundary) aquifer resources management, their significance and sustainable management: a framework document. IHP-VI, International Hydrological Programme, Non Serial Publications in Hydrology SC-2001/WS/40. Paris, France: UNESCO.

Phil. Trans. R. Soc. A (2010) 
1030

1031

1032

1033

1034

1035

1036

1037

1038

1039

1040

1041

1042

1043 Q9

1044

1045

1046

1047

1048

1049

1050

1051

1052

1053

1054

1055

1056

1057

1058

1059

1060

$1061_{\mathrm{Q} 3}$

1062

1063

1064

1065

1066

1067

1068

1069

1070

1071

1072

1073

1074

1075

1076

1077

1078
Rimmer, A. \& Salingar, Y. 2006 Modelling precipitation-stream flow processes in Karst basin: the case of the Jordan River sources, Israel. J. Hydrol. 331, 524-542. (doi:10.1016/ j.jhydrol.2006.06.003)

Samuels, R., Rimmer, A. \& Alpert, P. 2009 Effect of extreme rainfall events on the water resources of the Jordan River. J. Hydrol. 375, 513-523. (doi:10.1016/j.jhydrol.2009.07.001)

Struckmeier, W. F., Gilbrich, W. H., Gun, J. v. d., Puri, S., Richts, A., Winter, P. \& Zaepke, M. 2006 WHYMAP and the world map of Transboudary Aquifer Systems at the scale of 1:50000 000. In Special Edition for the 4th World Water Forum, Mexico City, March 2006. See http://www.whymap.org (accessed June 2010).

Suppan, P., Kunstmann, H., Heckl, A. \& Rimmer, A. 2008 Impact of climate change on water availability in the Near East. In Climatic changes and water resources in the Middle East and North Africa (eds F. Zereini \& H. Hotzl), pp. 45-57. Springer.

Tarawneh, Q. \& Kadoğlu, M. 2003 An analysis of precipitation climatology in Jordan. Theor. Appl. Climatol. 47, 123-136. (doi:10.1007/s00704-002-0705-5)

Tipping, R. 2007 Long-term landscape evolution of the Wadis Dana Faynan and Ghuwayr. In The early prehistory of Wadi Faynan, Southern Jordan: archaeological survey of Wadis Faynan, Ghuwayr and Al Bustan and evaluation of the Pre-Pottery Neolithic A Site of WF16 (eds B. Finlayson \& S. J. Mithen), Wadi Faynan Series 1, Levant Supplementary Series 4, pp. 14-46 (ISBN 1-84217-212-3).

United States Department of Agriculture. 2006 Jordan-Grain and Feed Report Annual 2006, Global Agricultural Information Network (GAIN) Report.

United States Statistics Division. 2010 See http://unstats.un.org/unsd/default.htm (accessed January 2010).

US Geological Survey. 2006 Application of methods for analysis of rainfall intensity in areas of Israeli, Jordanian and Palestinian interest. Reports of the Executive Action Team, Middle East Water Data Banks Project.

Wade, A. J., Durand, P., Beaujouan, V., Wessel, W. W., Raat, K. J., Whitehead, P. G., Butterfield, D., Rankinen, K. \& Lepisto, A. 2002 Towards a generic nitrogen model of European ecosystems: INCA, new model structure and equations. Hydrol. Earth Syst. Sci. 6, 559-582. (doi:10.5194/hess-6-559-2002)

Q3 Wade, A. J., Black, E., Flynn, N. \& Whitehead, P. In press $a$. The impacts of climate change on rainfall-runoff in the upper River Jordan: methodology and first projections. In Water, life and civilisation: climate, environment and society in the Jordan Valley (eds S. Mithen \& E. Black). Cambridge,UK: Cambridge University Press.

3 Wade, A. J. et al. In press $b$. The hydrology of the Wadi Faynan. In Water, life and civilisation: climate, environment and society in the Jordan Valley (eds S. Mithen \& E. Black). Cambridge: Cambridge University Press.

Whitehead, P. G., Wilson, E. J. \& Butterfield, D. 1998 A semi-distributed Integrated Nitrogen Model for Multiple Source Assessment in Catchments (INCA): part 1-model structure and process equations. Sci. Total Environ. 210/211, 547-588. (doi:10.1016/S0048-9697(98)00037-0)

Wilby, R. L. \& Harris, I. 2006 A framework for assessing uncertainties in climate change impacts: low-flow scenarios for the River Thames, UK. Water Resour. Res. 42, W02 417. (doi:10.1029/ 2005WR004065)

Q3 Wilby, R. L.et al. In press. A review of climate risk information for adaptation and development planning. Int. J. Climatol. 